\title{
Comparative susceptibility of three fish cell lines to Egtved virus, the virus of viral haemorrhagic septicaemia (VHS)
}

\author{
N. J. Olesen, P. E. Vestergård Jørgensen
}

National Veterinary Laboratory, Hangøvej 2, DK-8200 Århus N, Denmark

\begin{abstract}
Susceptibility of the 3 fish cell lines BF-2, EPC and CHSE-214 to Egtved virus [viral haemorrhagic septicaemia virus (VHSV)] was examined. Tissue specimens were examined from rainbow trout originating from trout farms suspected to be VHS infected and from a population of fish with VHSV carriers. The BF-2 cell line detected twice as many VHSV carriers as the other 2 cell lines and when used for titration of virus in fish tissue specimens gave titres 10 - or 20 fold higher than the EPC and CHSE-214 cell lines, respectively.
\end{abstract}

Viral haemorrhagic septicaemia (VHS), probably the most dreaded infectious disease in reared rainbow trout in Europe, is dealt with in the disease legislation of many European countries. Similarly, in a proposed European Community (EC) directive concerning transfer of live fish inside the Community after January 1993, the disease is listed as one of the major concerns and it is foreseen that regions which are free from VHS will implement surveillance procedures so as to obtain official VHS-free status. The value of surveillance depends heavily on the quality of the diagnostic procedure used. Sensitive and specific diagnosis of VHS is obtained by inoculation of membrane-filtered or antibiotic-treated tissue homogenate from affected fish into cultures of fish cells followed by serological identification of agents inducing cytopathic effect (CPE) in the cultures. A number of widely distributed cell lines such as RTG-2 (Wolf \& Quimby 1962), FHM (Gravell \& Malsberger 1965), EPC (Fijan et al. 1983), and CHSE214 (Fryer et al. 1965) have been used for isolation of Egtved virus [viral haemorrhagic septicaemia virus (VHSV)] (Wolf 1988). In addition BF-2 cells (Wolf et al. 1966) have been routinely used for some years in the national Danish VHS control program on the basis of preliminary susceptibility studies (authors' unpublished results). However, apparently no adequate information about the relative sensitivity of the cell lines has been published, since most sensitivity studies have been performed using cell-culture-adapted laboratory strains of virus of unknown passage level. The present study attempts to provide data concerning the relative susceptibility of 3 selected cell lines to virus not previously adapted to cell culture conditions, i.e. virus present in the tissues of naturally infected rainbow trout. We attempted to make the material as representative as possible by using infected fish from 35 different Danish trout farms and by using material from acutely diseased fish as well as material from apparently healthy VHS survivors. RTG-2 and FHM cell lines were disregarded in the study because of growth characteristics involving quick acidification of medium and recurrent problems with detachment of cells from plastic surfaces, respectively. For a recent review of VHS see Wolf (1988).

\section{MATERIALS AND METHODS}

Tissue pools including kidney, spleen and brain specimens from rainbow trout from 34 trout farms were collected by the Veterinary Services or trout farm owners for virological examination at the laboratory. High mortality rates were observed in 19 of the farms with fish showing typical symptoms of VHS. In the remaining 15 farms slight mortalities caused by diseases with uncharacteristic symptomatology were observed. The organs, excised from freshly killed diseased fish, were mailed on ice and received at the laboratory within $24 \mathrm{~h}$. Tissue specimens were processed according to standard procedures. Briefly, specimens were homogenized by means of mortars, pestles, and quartz sand, resuspended in approximately 4 volumes of cell culture medium (Eagles MEM supplemented with $10 \%$ foetal bovine serum, Tris buffer and antibiotics), and centrifuged at $3000 \mathrm{~g}$ for $15 \mathrm{~min}$ at $4{ }^{\circ} \mathrm{C}$. Supernatants were stored at $-80^{\circ} \mathrm{C}$ until examined. Tissue samples from these 34 farms are indicated by (I) in this paper. 
In one additional trout farm, known to be infected with VHSV, 105 rainbow trout (mean weight $150 \mathrm{~g}$ ) were collected about $4 \mathrm{wk}$ after the termination of a VHS outbreak and brought to the laboratory where pieces of kidney, spleen and brain were excised, processed as 105 individual samples and stored at $-80^{\circ} \mathrm{C}$ until examined. Tissue samples from this source are indicated by (II).

Frozen samples (I) were thawed in cold water and titrated in parallel in $24 \mathrm{~h}$ old cultures of BF-2, EPC, and CHSE-214 cells, respectively, in 96-well microtiter plates, using $25 \mu \mathrm{l}$ inoculum per well (containing $150 \mu \mathrm{l}$ cell culture medium) and 6 wells for each of 8 successive 10 -fold dilution steps starting at the original 1:5 dilution of the tissue specimens. Plates were incubated at $15^{\circ} \mathrm{C}$ until examined microscopically for cytopathic effect (CPE) $7 \mathrm{~d}$ later. If no CPE was observed the samples were subcultivated by inoculating pooled aliquots of medium from wells with the 3 lowest sample dilutions into fresh cell cultures in quantities of $25 \mu \mathrm{l}$ per well using 6 wells per dilution for each of 3 successive 10 -fold dilution steps starting at the undiluted pooled aliquots. Incubation for an additional $7 \mathrm{~d}$ period was performed before final reading. Concentrations of virus detected were expressed as tissue culture infective doses $50 \%\left(\mathrm{TCID}_{50}\right) \mathrm{ml}^{-1}$. Presence of Egtved virus in all samples giving CPE was verified by neutralization tests or immunofluorescence (Jørgensen 1974)

The 105 individual samples (II) were examined in parallel in $24 \mathrm{~h}$ old cultures of BF-2, EPC, and CHSE214 cells, respectively, in 24 -well trays, as follows: One well, containing $1.5 \mathrm{ml}$ of cell culture medium, received $150 \mu \mathrm{l}$ of sample. Sample and medium were carefully mixed in the well, and $150 \mu$ of the mixture transferred to another well. Mixing was repeated in the second well and $150 \mu$ transferred to a third well. Each sample thus was examined in three 10 -fold dilution steps (final dilution approximately $10^{-1}, 10^{-2}$, and $10^{-3}$ ) in each cell line. Inoculated cultures were incubated, examined and subcultivated as described above. Confirmation of VHSV in samples exhibiting CPE was obtained by ELISA (Olesen \& Jørgensen 1991)

\section{RESULTS}

Among the 34 samples (I) examined, 20 were VHSVpositive in BF-2, 19 in EPC, and 18 in CHSE-214 during the first cell culture passage (Fig. 1). Average titres of positive samples in each of the cell lines were $6 \times 10^{6}$ $(\mathrm{BF}-2), 3 \times 10^{5}(\mathrm{EPC})$ and $6 \times 10^{5}$ (CHSE-214) tissue culture infective doses ( $\operatorname{TCID}_{50}$ ) $\mathrm{ml}^{-1}$ tissue suspension. Positive titres in BF-2 cells ranged from $1 \times 10^{3}$ to $9 \times 10^{8} \mathrm{TCID}_{50} \mathrm{ml}^{-1}$. The highest titre in EPC cells was $4 \times 10^{7}$ and in CHSE-214 cells $1 \times 10^{8} \mathrm{TCID}_{50} \mathrm{ml}^{-1}$. One sample (No. 19) which was negative in the first CHSE-214 cell culture passage became positive during subcultivation, so that both EPC and CHSE-214 cells gave 19 positive samples versus the 20 observed for BF2 cells. Sample no. 20 (Fig. 1) which was positive only in BF-2 cells originated from 1 of the trout farms with diseases of uncharacteristic symptomatology.

Among the 105 individually examined fish (II) only 2 showed gross pathological changes indicative of VHS. Sixty-six samples were found to be VHSV positive in BF-2 cells, 36 in CHSE-214 and 33 in EPC after subcul-

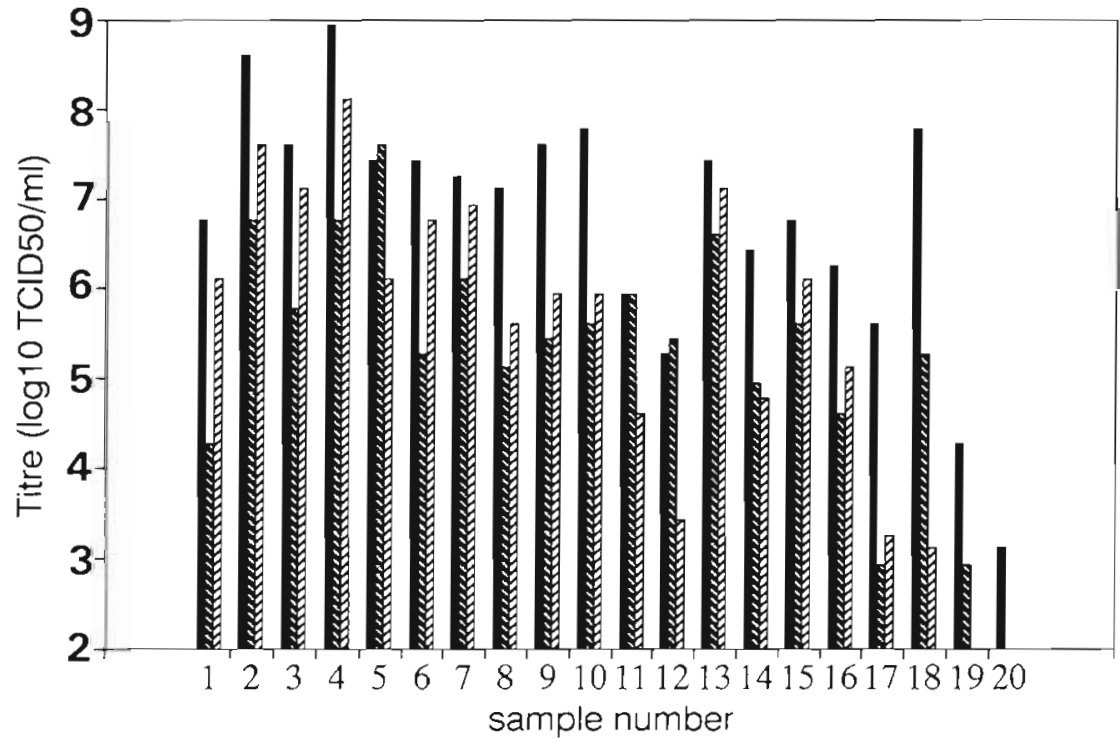

$\mathrm{BF}-2$
EPC

YIIIS CHSE-214
Fig. 1 VHSV titres in 20 tissue samples examined on BF-2,EPC, and CHSE214 cells, respectively. Titres are expressed as TCID $\mathrm{Sm}^{-1}$ of tissue suspension (which represents a $1: 5$ dilution of the tissue) 
tivation (Fig. 2). Subcultivation increased the number of positive samples by $61 \%$ in BF-2, $20 \%$ in CHSE214 , and $22 \%$ in EPC cells. Thirty samples (29\%) were positive only in BF-2, 2 (2\%) positive only in CHSE214 , and none positive only in EPC. One sample (1\%) was positive in both CHSE-214 and EPC but negative in $\mathrm{BF}-2$.

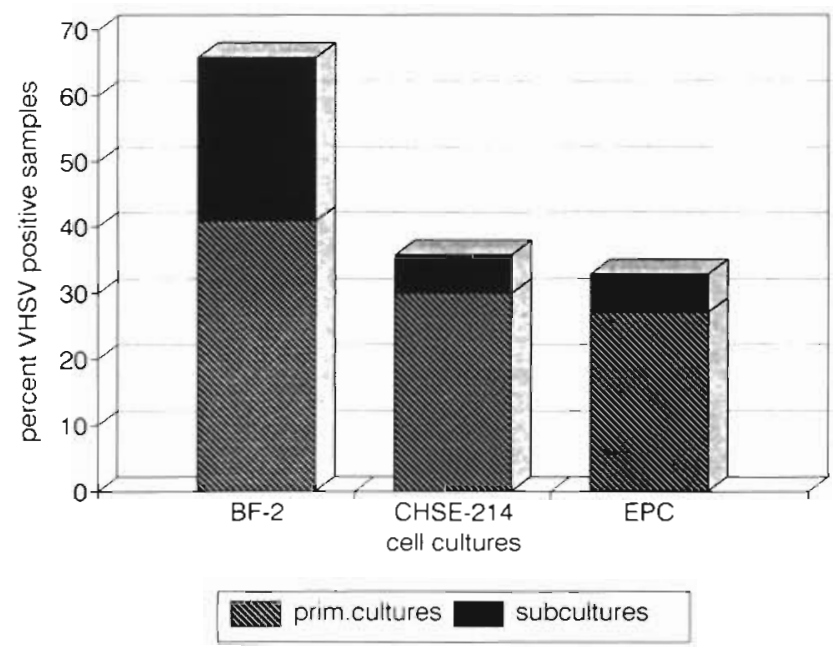

Fig. 2. Ability of 3 cell lines (BF-2, CHSE-214, and EPC) to detect Egtved virus carriers among 105 individually examined fish

\section{DISCUSSION}

The BF-2 cell line was found to be more susceptible to VHSV than the EPC and CHSE-214 cell lines. The virus titres were 10 - to 20 -fold higher in the BF-2 cell line than in the CHSE-214 and EPC cell lines, respectively. When examining individual fish with low virus concentrations, the BF-2 cell line detected about twice as many VHSV carriers as the EPC and CHSE-214 cell lines. For virus isolation tests on tissue specimens from rainbow trout with gross pathological changes typical of VHS, all the cell lines seem to have a sufficient susceptibility. For screening of seemingly healthy trout populations for the presence of VHSV carriers with low concentrations of virus, however, the BF-2 cell line clearly is the one of choice. The data also confirm the value of subcultivating samples before final reading. Since the susceptibility of a cell line to a virus may vary considerably between cell stocks in different laboratories, it is recommended that the differences Responsible Subject Editor: W. Ahne, Munich, Germany observed in the present study are checked in other laboratories involved in VHS surveillance work. It deserves mentioning in this connection that J. Winton, Seattle, U.S.A. (pers. comm.) in a recent study has observed considerable differences in the VHSV susceptibility of different stocks of EPC and CHSE-214 cells. Considering the importance of infectious hematopoietic necrosis (IHN) in Europe, as reflected by its inclusion in the EC directive concerning transfer of live fish inside the Community after January 1993, it would be worthwhile to also perform a comparative study of the susceptibility of selected cell lines to IHN virus not adapted to cell cultures. Due to the apparent absence of IHN in Danish fish populations the study cannot be performed in the present laboratory, but should be performed in a country where IHN occurs with a certain minimal frequency to ensure access to tissues from naturally infected fish.

Since certification for VHS and IHN freedom will frequently have to be done in parallel, it would be ideal if the same cell line could be used for screening for both viruses. In the present form the $\mathrm{EC}$ proposals for surveillance procedures for VHS and IHN require use of 2 cell lines, i.e. BF-2 and in addition either EPC or FHM (W. Daelman, EC Commission, Brussels, Belgium, pers. comm.).

\section{LITERATURE CITED}

Fijan, N., Sulimanovíc, D., Bearzotti, M., Muziníc, D., Zwillenberg, L. O., Chilmonczyk, S., Vautherot, J. F., Kinkelin, P. de (1983). Some properties of the epithelioma papulosum cyprini (EPC) cell line from carp (Cyprinus carpio). Ann. Virol. (Inst. Pasteur) 134E: 207-220

Fryer, J. L., Yusha, A., Pilcher, K. S. (1965). The in vitro cultivation of tissue and cells of Pacific salmon and steelhead trout. Ann. N.Y. Acad. Sci. 126: 566-586

Gravell, M., Malsberger, R. G. (1965). A permanent cell line from the fathead minnow (Pimephales promelas). Ann. N.Y. Acad. Sci. 126: 555-565

Jørgensen, P. E. V. (1974). A study of viral diseases in Danish. rainbow trout. Their diagnosis and control. Ph.D. thesis, Royal Veterinary and Agricultural University, Copenhagen

Olesen, N. J., Jørgensen, P. E. V. (1991). Rapid detection of viral haemorrhagic septicaemia virus in fish by ELISA. J. appl. Ichthyol. 7: 183-186

Wolf, K., Quimby, M. C. (1962). Established eurythermic line of fish cells in vitro. Science 135: 1065-1066

Wolf, K., Gravell, M., Malsberger, R. G. (1966). Lymphocystis virus: Isolation and propagation in centrarchid fish cell lines. Science 151: 1004-1005

Wolf, K. (1988). Fish viruses and fish viral diseases. Cornell University Press, Ithaca, New York

Manuscript first received: August 26, 1991 Revised version accepted: February 7, 1992 